\title{
(6.
}

\section{COMPOSICIÓN DE LOS GRUPOS DE PAÍSES}

Unión Europea (28): agrupa a 28 países y se compone de la zona euro (19) y del resto de la zona UE (9).

La zona euro agrupa a Alemania, Austria, Bélgica, Chipre, Eslovaquia, Eslovenia, España, Estonia, Finlandia, Francia, Grecia, Irlanda, Italia, Letonia, Lituania, Luxemburgo, Malta, Países Bajos y Portugal.

Resto UE: Bulgaria, Croacia, Dinamarca, Hungría, Polonia, Reino Unido, República Checa, Rumania y Suecia.

Resto de Europa: Albania, Andorra, Bielorrusia, Bosnia-Herzegovina, Ciudad del Vaticano, Gibraltar, Islandia, Islas Feroë, Kosovo, Liechtenstein, Macedonia, Moldavia, Montenegro, Noruega, Rusia, San Marino, Serbia, Suiza, Turquía y Ucrania.

América del Norte comprende: Bermudas, Canadá, Estados Unidos, Groenlandia (Dinamarca) y San Pedro y Miquelón.

América Latina: Argentina, Bolivia, Brasil, Chile, Colombia, Costa Rica, Cuba, Ecuador, El Salvador, Guatemala, Haití, Honduras, México, Nicaragua, Panamá, Paraguay, Perú, República Dominicana, Uruguay y Venezuela.

ASEAN: Brunei, Camboya, Filipinas, Indonesia, Laos, Malasia, Myanmar, Singapur, Tailandia y Vietnam.

Países BRICS agrupa a Brasil, Rusia, India, China y Sudáfrica.

Mercosur* es el mercado común de América del Sur formado por: Argentina, Brasil, Paraguay y Uruguay.

NAFTA son los países del acuerdo comercial que agrupa a Canadá, Estados Unidos y México.

La OCDE engloba a 35 países: Alemania, Australia, Austria, Bélgica, Canadá, Chile, Corea del Sur, Dinamarca, Eslovenia, España, Estados Unidos, Estonia, Finlandia, Francia, Grecia, Hungría, Irlanda, Islandia, Israel, Italia, Japón, Letonia, Luxemburgo, México, Noruega, Nueva Zelanda, Países Bajos, Polonia, Portugal, Reino Unido, República Checa, República Eslovaca, Suecia, Suiza y Turquía.

La OPEP es la Organización de Países Exportadores de Petróleo y engloba a 14 países: Angola, Arabia Saudí, Argelia, Ecuador, Emiratos Árabes Unidos, Gabón, Guinea Ecuatorial, Irak, Irán, Kuwait, Libia, Nigeria, Qatar y Venezuela.

Oriente Medio agrupa a: Arabia Saudí, Bahrein, Cisjordania y Gaza, Emiratos Árabes Unidos, Irán, Irak, Israel, Jordania, Kuwait, Líbano, Omán, Qatar, Siria y Yemen.

*La República Bolivariana de Venezuela se encuentra suspendida en todos los derechos y obligaciones inherentes a su condición de Estado parte de Mercosur, de conformidad con lo dispuesto en el segundo párrafo del artículo $5^{\circ}$ del Protocolo de Ushuaia. 